\title{
ABSTRAK \\ STUDI KASUS PADA KELUARGA Ny "H" DENGAN ANGGOTA KELUARGA YANG MENGALAMI GANGGUAN KESEHATAN TB PARU KELURAHAN MANGASA KECAMATAN TAMALATE KOTA MAKASSAR
}

\author{
*Trimaya Cahya Mulat* \\ Email;trimayacm11@gmail.com \\ Dosen tetap Akademi Keperawatan Sandi Karsa
}

Pembangunan kesehatan bertujuan agar setiap penduduk mampu hidup sehat sehingga dapat mewujudkan derajat kesehatan masyarakat yang optimal, yang merupakan salah satu unsur kesejahteraan umum dari tujuan pembangunan kesehatan.

Tujuan Penulisan,Memperoleh gambaran yang nyata tentang pelaksanaan penerapan asuhan keperawatan keluarga Ny "H" dengan anggota keluarga menderita TB paru.

Duvall, Keluarga adalah sekumpulan orang yang dihubungkan oleh ikatan perkawinan, adopsi, kelahiran yang bertujuan menciptakan dan mempertahankan budaya yang umum, meningkatkan perkembangan fisik, mental, emosional dan social dari tiap anggota.WHO, 1969, Keluarga adalah anggota rumah tangga yang saling berhubungan melalui pertalihan darah, adopsi atau perkawinan.

TB Paru adalah penyakit infeksi menular, yang terutama menyerang perenkim paru. Tuberculosis dapat juga ditularkan ke bagian tubuh lainnya, termasuk meningens, ginjal, tulang dan nodus limfe.( Suzanne C. Smeltzer \& Brenda G. Bare, 2001)

Kesimpulan Dalam melaksanakan pengkajian terhadap keluarga Ny."H" penulis memperoleh data bahwa anggota keluarga Ny. H mengalami penyakit TB Paru. Gejala penyakit TB Paru dalam konsep dasar tidak jauh beda dengan tinjauan kasus namun ada beberapa gejala yang tidak muncul seperti tidak ada nafsu makan, keringat malam, sakit kepala, meriang, nyeri otot dan demam. Hal ini disebabkan karena keluhan tersebut umumnya muncul pada awal terjadinya penyakit, sementara pada klien An. R menderita batuk sudah lama $( \pm 4$ bulan yang lalu)., Pada asuhan keperawatan keluarga Ny. H ditemukan 3 masalah kesehatan yaitu anggota keluarga menderita penyakit TB Paru, resiko terjadinya penyakit akibat personal hygiene yang kurang. Dan resiko terjadinya penyakit (diare, typhoid, DBD) akibat lingkungan yang tidak memenuhi syarat kesehatan dan Dalam perencanaan penulis melibatkan keluarga dalam menentukan masalah dan kebutuhan keperawatan keluarga, menentukan prioritas masalah, memilih tindakan yang tepat dalam proses perawatan TB Paru.

Intervensi yang dilakukan untuk mengatasi masalah tersebut yaitu memberikan penyuluhan dan motivasi kepada keluarga, Tahap pelaksanaan asuhan keperawatan keluarga Ny."H" dengan anggota keluarga menderita TB Paru didasarkan pada perencanaan yang telah disusun penulis bersama keluarga.,Pada tahap evaluasi masalah yang ditemukan tidak semuanya dapat teratasi (hanya sebahagian). Hal ini disebabkan karena terbatasnya waktu, pola kebiasaan lingkungan yang tidak menunjang kesehatan dan sumber daya keluarga, Penerapan proses keperawatan pada keluarga terbukti sangat efektif terutama dalam mengatasi masalah-masalah kesehatan yang ada dalam suatu keluarga.

Saran Pengkajian keperawatan keluarga harus dilakukan secara sistematis dan komprehensif untuk memperoleh data yang seakurat mungkin dalam menegakkan diagnosa keperawatan, Pendidikan kesehatan atau penyuluhan perlu diberikan kepada individu, keluarga dan masayarakat secara luas dan menyeluruh. Hal ini diharapkan agar individu, keluarga dan masyarakat berperan aktif dalam memelihara dan meningkatkan derajat kesehatan khususnya penyakit TB paru.

Kata kunci; tb paru, kesehatan keluarga 


\section{Pendahuluan}

Pembangunan kesehatan bertujuan agar setiap penduduk mampu hidup sehat sehingga dapat mewujudkan derajat kesehatan masyarakat yang optimal, yang merupakan salah satu unsur kesejahteraan umum dari tujuan pembangunan kesehatan.

Secara nasional pembangunan di bidang kesehatan baik jangka pendek, menengah, maupun jangka panjang pada dasarnya mengarah kepada pencapaian kemampuan hidup sehat bagi setiap penduduk agar dapat terwujud derajat kesehatan yang optimal sebagai salah satu unsur kesejahteraan umum dari tujuan nasional.(Depkes RI 1999).

Untuk itu pelaksanaan keperawatan harus dilakukan secara profesional sehingga dapat memenuhi kebutuhan masyarakat sesuai perkembangan ilmu pengetahuan dan tekhnologi khususnya dalam bidang perawatan kesehatan masyarakat. Ilmu keperawatan dewasa ini semakin berkembang sejalan dengan tingkat kehidupan manusia, semula pelayanan keperawatan berfokus pada individu yang sakit, tetapi dewasa ini keperawatan difokuskan kepada individu, keluarga, dan masyarakat baik sehat maupun sakit.

Salah satu penyakit yang mempunyai insiden yang banyak diderita di masyarakat adalah penyakit infeksi saluran pernafasan khususnya TB Paru. Penyakit tuberculosa masih merupakan problem kesehatan masyarakat terutama pada negara-negara berkembang karena Micobacterium Tuberculosis (TB) telah menginfeksi sepertiga penduduk dunia. Menurut WHO sekitar 8 juta penduduk dunia diserang TB dengan kematian 3 juta orang per tahun (WHO, 1993).

WHO memperkirakan setiap tahun menjadi 583.000 kasus baru tuberkulosis dengan kematian sekitar 140.000, secara kasar diperkirakan setiap 100.000 penduduk Indonesia terdapat 130 penderita baru tuberculosis dengan BTA positif. (http://www.tbcindonesia.com.2009)

Penemuan kasus TBC di Indonesia (CDR=Case Detection Rate ) pada tahun 2005 adalah $68 \%$, telah mendekati target global untuk penemuan kasus pada tahun 2005 sebesar $70 \%$ dan target 2007 menjadi 74\%. Sedangkan angka keberhasilan pengobatan (Success Rate $=$ SR) mencapai $89,7 \%$ melebihi target WHO sebesar $85 \%$. Jumlah kasus TBC yang ditemukan meningkat secara nyata dalam beberapa tahun terakhir. Angka penemuan kasus BTA positif baru meningkat dari 38\% di tahun 2003 menjadi 54\% di tahun 2004 sebagai hasil ekspansi DOTS. (http://www.detiknews.com.2009)

Data epidemiologi menunjukkan trend penurunan insidens TBC di Indonesia yaitu 128/100.000 penduduk pada tahun 1999 menjadi 107/100.000 penduduk pada tahun 2005. Namun demikian berdasarkan survey pravalensi Nasional TBC oleh Badan Litbangkes tahun 2004, menunjukkan sebaran insidens TBC per 100.000 penduduk yang variatif dalam 4 regional, yakni Yogya/Bali (64/100.000 penduduk), Jawa (107/100.000 penduduk), Sumatera (160/100.000 penduduk) dan KTI (210/100.000 penduduk).

Berdasarkan data yang diperoleh dari dinas kesehatan kota Makassar, penyakit TB paru menyerang warga Makassar sebanyak 1647 orang (dari bulan Januari sampai Juni 2009). Angka penderita penyakit tersebut adalah yang terbanyak karena hanya dalam 3 triwulan hasilnya sudah melebihi yang diperhitungkan. Bahkan, dibandingkan tahun 2008 lalu ada kecenderungan jumlah penderita TB paru menurun sebanyak 3443 orang selama satu tahun "peningkatan jumlah penderita penyakit TB paru ini harus menjadi bahan evaluasi”. Jika dihitung-hitung peningkatannya pada tahun 2009 mencapai 6,13\%. (Anwar, 2007)

Dari data diatas dapat menggambarkan tingginya angka kesakitan penyakit TB Paru yang dapat menularkan kepada orang sekitarnya bila tidak di lakukan pengobatan. Untuk mengurangi jumlah pasien penyakit tuberculosa paru di masyarakat yaitu dengan cara meningkatkan pengetahuannya tentang penyakit TB Paru ini.

Berdasarkan uraian tersebut di atas dan hasil penentuan kasus pada ujian akhir program, maka penulis merasa perlu untuk menulis kasus ini sebagai karya ilmiah dengan judul "Asuhan Keperawatan Pada Keluarga Ny. " $H$ " dengan Anggota Keluarga Menderita Penyakit TB Paru di Wilayah Kerja Puskesmas Mangasa RT A RW 08 Kelurahan Mangasa Kecamatan Tamalate Kota Makassar.

\section{Tujuan Penulisan}

Memperoleh gambaran yang nyata tentang pelaksanaan penerapan asuhan keperawatan keluarga Ny "H" dengan anggota keluarga menderita TB paru.

\section{Manfaat Penulisan}

1. Institusi Pendidikan

Dapat menjadi bacaan ilmiah, kerangka perbandingan untuk mengembangkan ilmu keperawatan serta menjadi sumber informasi bagi mereka yang ingin mengadakan penelitian lebih lanjut.

2. Puskesmas.

Sebagai bahan masukan dalam penerapan asuhan keperawatan keluarga khususnya keluarga dengan masalah penyakit TB Paru.

3. Keluarga/Masyarakat

Agar keluarga dapat mengetahui dan memahami lebih jauh tentang penyakit TB Paru dan juga menegetahui langkah-langkah perawatan, pengobatan dan pencegahan untuk menangani masalah tersebut. 


\section{Penulis}

a. Menambah pengetahuan dan pengalaman nyata dalam penerapan asuhan keperawatan keluarga khususnya mengenai penyakit TB Paru.

b. Sebagai persyaratan dalam menyelesaikan pendidikan di Akademi keperawatan Sandi Karsa Jurusan Keperawatan Program Studi Keperawatan Makassar.

\section{Tinjauan Teori}

\section{Konsep Dasar Keperawatan Keluarga}

Banyak ahli menguraikan pengertian keluarga sesuai dengan perkembangan sosial masyarakat. Berikut ini akan penulis kemukakan pengertian keluarga menurut beberapa ahli :

a. Duvall

Keluarga adalah sekumpulan orang yang dihubungkan oleh ikatan perkawinan, adopsi, kelahiran yang bertujuan menciptakan dan mempertahankan budaya yang umum, meningkatkan perkembangan fisik, mental, emosional dan social dari tiap anggota.

b. WHO, 1969

Keluarga adalah anggota rumah tangga yang saling berhubungan melalui pertalihan darah, adopsi atau perkawinan.

c. Bergess, 1962

Yang dimaksud dengan keluarga adalah:

1) Terdiri dari kelompk orang yang mempunyai ikatan perkawinan, keturunan/hubungan sedarah atau hasil adopsi.

2) Anggota tinggal bersama dalam satu rumah

3) Anggota berinteraksi dan berkomunikasi dalam peran sosial

4) Mempunyai kebiasaan/kebudayaan yang berasal dari masyarakat tetapi mempunyai keunikan tersendiri.

d. Helvie, 1981

Keluarga adalah sekelompok manusia yang tinggal dalam satu rumah tangga dalam kedekatan yang konsisten dan hubungan yang erat.

e. Salvicion G. Bailon dan Aracelis Maglaya, 1989

Keluarga adalah dua atau lebih dari dua individu yang tergabung karena hubungan darah, hubungan perkawinan atau pengangkatan dan mereka hidup dalam suatu rumah tangga, berinteraksi satu sama lain, dan di dalam peranna masing-masing menciptakan serta mempertahankan kebudayaannya.

f. Departemen kesehatan R.I. 1998

Keluarga adalah unit terkecil dari suatu masyarakat yang terdiri dari kepala keluarga dan beberapa orang yang terkumpul dan tinggal disuatu tempat dbawah suatu atap dalam keadaan saling ketergantungan. (Mubarak Iqbal Wahid, 2006)
Dari pengertian tersebut diatas tentang keluarga maka penulis dapat menyimpulkan bahwa karakteristik keluarga adalah :

1) Terdiri dari dua atau lebih individu yang diikat oleh hubungan darah, perkawinan atau adopsi.

2) Anggota eluarga biasanya hidup bersama atau jika terpisah mereka tetap memperhatikan satu sama lain.

3) Anggota keluarga berinteraksi satu sama lain dan masing-masing mempunayai peran social:suami, isteri, anak, kakak, adik.

4) Mempunyai tujuan yaitu : menciptakan dan mempertahankan budaya dan meningkatkan perkembagan fisik, psikologis dan sosial anggota.

Keluarga merupakan suatu sistem, mempunyai anggota yaitu: ayah, ibu, dan anak atau semua individu yang tinggal didalam rumah tangga tersebut yang saling berinteraksi, interelasi, dan interdependensi untuk mencapai tujuan bersama.

\section{Struktur Keluarga}

Struktur keluarga terdiri dari bermacam-macam, diantaranya :

a. Patrilineal : adalah keluarga sedarah yang terdiri dari sanak saudara sedarah dalam beberapa generasi dimana hubungan itu disusun melalui jalur garis ayah.

b. Matrilineal : adalah keluarga sedarah yang terdiri dan saudara sedarah dalam beberapa generasi dimana hubungan itu disusun melalui jalur garis ibu.

c. Matrilokal : adalah sepasang suami istni yang tinggal bersama keluarga sedarah istri.

d. Patriokal : adalah sepasang suami istri yang tinggal bersama keluarga sedarah suami.

e. Keluarga kawin : adalah hubungan suami istri sebagai dasar bagi pembinaan keluarga, dan beberapa sanak saudara yang menjadi bagian keluarga karena adanya hubungan suami atau istri.

Ciri-ciri struktur keluarga Anderson Carter :

1) Terorganisasi : saling berhubungan. saling ketergantungan antara anggota keluarga.

2) Ada keterbatasan : setiap anggota memiliki keterbatasan tetapi mereka juga mempunyai keterbatasan dalam menjalankan fungsi dan tugasnya masing-masing.

3) Ada perbedaan dan kekuasaan : setiap anggota keluarga mempunyai peranan dan fungsinya masing-masing.

(Nasrul Effendi, Dasar-dasar Keperawatan Masyarakat, Hal 33)

\section{Tipe Keluarga}


Agar dapat mengupayakan peran serta keluarga dalam meningkatkan derajat kesehatan maka perawat perlu memahami dan mengetahui berbagai tipe keluarga :

a. Keluarga Inti (Nuclear Family)

Keluarga inti terdiri dari : ayah, ibu dan anak yang tinggal dalam satu rumah ditetapkan oleh sanksi-sanksi legal dalam suatu ikatan perkawinan, satu/keduanya dapat bekerja diluar rumah.

4) Keluarga Besar (Extended Family)

Adalah keluarga inti ditambah dengan anak saudara misalnya : nenek, kakek, keponakan, saudara sepupu, paman, bibi dan lain sebagainya.

5) Reconstituted nuclear

Pembentukan baru dari keluarga inti melalui perkawinan kembali suami/isteri, tinggal dalam pembentukan satu rumah dengan anak-anaknya, baik itu bawaan dari perkawinan lama maupun hasil dari perkawinan baru. Satu atau keduanya dapat bekerja di luar rumah.

6) Niddle age/agin couple

Suami sebagai pencari uang, isteri dirumah/kedua-duanya bekerja dirumah, anak-anak sudah meninggalkan rumah karena sekolah/perkawinan/meniti karier.

7) Dyadic nuclear

Suami isteri yang sudah berumur dan tidak mempunyai anak, keduanya/salah satu bekerja di luar rumah.

8) Single parent

Satu orang tua sebagai akibat perceraian/kematian pasangannya san anak-anak dapat tinggal dirumah/di luar rumah.

9) Dual carrier

Suami insteri atau keduanya orang karier dan tanpa anak.

10) Commuter married

Suami isteri/keduanya orang karier dan tinggal terpisah pada jarak tertentu, keduanya saling mencari pada waktuwaktu tertentu

11) Single adult

Wanita atau pria dewasa yang tinggal sendiri dengan tidak adanya keinginan untuk kawin.

12) Three generation

Tiga generasi atau lebih tinggal salam satu rumah.

13) Instusional

Anak-anak atau orang-orang dewasa tinggal dalam suatu panti-panti.

\section{4) Communal}

Satu rumah terdiri dari dua/lebih pasangan yang monogamy dengan anak- anaknya dan bersama-sama dalam penyediaan fasilitas.

15) Group marriage

Satu perumahan terdiri dari orang tua dan keturunannya di dalam datu kesatuan keluarga dan tiap individu adalah kawin dengan yang lain dan semula adalah orang tua dari anak-anak.

16) Unmarried parent and child

Ibu dan anak dimana perkawinan tidak dikehendaki, anaknya di adopsi.

17) Cohibing cuple

Dua orang/satu pasangan yang tinggal bersama tanpa kawin.

(Mubarak Iqbal Wahid, 2006 : 257-258)

\section{Peran Keluarga}

Peran keluarga menggambarkan seperangkat perilaku interpersonal, sifat, kegiatan yang berhubungan dengan individu dalam posisi dan situasi tertentu atau peranan individu dalam keluarga didasari oleh harapan dan pola perilaku dari keluarga, kelompok, dan masyarakat. Berbagai peranan yang terdapat dalam keluarga adalah sebagai berikut:

a. Peranan ayah

Ayah sebagai suami dari istri dan anakanak. Berperan sebagai pencari nafkah, pendidik, pelindung dan pemberi rasa aman, sebagai anggota dari kelompok sosalnya serta sebagai anggota masyarakat dari lingkungannya.

b. Peranan ibu

Sebagai istri dan ibu dari anak-anaknya. Ibu mempunyai peranan untuk mengurus rumah tangga, sebagai pengasuh dan pendidik anak-anaknya, pelindung dan sebagai salah satu kelompok dari peranan sosialnya serta sebagai anggota masyarakat dari lingkungannya, disamping itu juga ibu dapat berperan sebagai pencari nafkah tambahan dalam keluarganya.

c. Peranan anak

Anak-anak melaksanakan peranan psiko-sosial sesuai dengan tingkat perkembangannya baik fisik, mental, sosial dan spiritual.

(Nasrul Efendi, 1998 : hal 34)

\section{Fungsi Keluarga}

Ada beberapa fungsi yang dijalankan di keluarga sebagai berikut:

a. Fungsi biologis

a) Untuk meneruskan keturunan

b) Memelihara dan membesarkan anak

c) Memenuhi kebutuhan gizi keluarga

b. Fungsi psikologis

1) Memberikan kasih sayang dan rasa aman

2) Memberikan perhatian diantara anggota keluarganya 
3) Membina pendewasaan kepribadian diantara anggota keluarga

4) Memberi identitas keluarga

c.Fungsi Sosialisasi

1) Memberi sosialisasi pada anak

2) Membentuk norma-norma tingkah laku sesuai dengan tingkat perkembangan masing-masing.

3) Meneruskan nilai-nilai budaya keluarga

d.Fungsi ekonomi

1) Mencari surnber-sumber penghasilan untuk memenuhi kebutuhan keluarga

2) Menabung untuk memenuhi kebutuhan-kebutuhan kelaurga dimasa yang akan datang.

e.Fungsi pendidikan

1) Menyekolahkan anak-anak untuk memberikan pengetahuan, keterampilan dan membentuk perilaku anak sesuai dengan bakat dan minat yang dimilikinya

2) Mempersiapkan anak-anak untuk kehidupan dewasa yang akan datang dalam memenuhi peranannya sebagai orang dewasa

3) Mendidik anak sesuai dengan tingkat-tingkat perkembangannya

(Mubarak Iqbal Wahid, 2006 : 264-265)

Secara umum fungsi keluarga (Friedman, 1998) adalah sebagai berikut :

a. Fungsi Afektif (the affective function) adalah fungsi keluarga yang utama untuk mengajarkan segala sesuatu untuk mempersiapakan anggota kelaurga berhubungan dengan orang lain. Fungsi ini dibutuhkan untuk perkembangan individu dan psikososial anggota keluarga.

b. Fungsi sosialisasi dan tempat bersosialisasi (socialization and socizl placement function) adalah fungsi mengembangkan dan tempat melatih anak untuk berkehidupan sosial sebelum meninggalkan rumah untuk berhubungan dengan orang lain diluar rumah.

c. Fungsi reproduksi (the reproductive function) adalah fungsi untuk mempertahankan generasi dan menjaga kelangsungan keluarga.

d. Fungsi ekonomi (the economic function), yaitu keluarga berfungsi untuk memenuhi kebutuhan kelaurga secara ekonomi dan tempat untuk mengembangkan kemampuan individu meningkatkan penghasilan untuk memenuhi kebutuhan kelaurga. e. Fungsi perawatan/pemeliharaan kesehatan (the health care function), yaitu fungsi untuk mempertahankan keadaan kesehatan anggota keluarga agar tetap memiliki produktivitas tinggi. Fungsi ini dikembangkan menjadi tugas kelaurga di bidang kesehatan.

\section{Tugas Keluarga Dibidang Kesehatan}

Sesuai fungsi pemeliharaan kesehatan, keluarga mempunyai tugas dibidang kesehatan yang perlu dipahami dan dilakukan , meliputi :

a. Mengenal masalah kesehatan keluarga.

b. Memutuskan tindakan kesehatan yang tepat bagi keluarga.

c. Merawat keluarga yang mengalami gangguan kesehatan.

d. Memodifikasi lingkungan keluarga untuk menjamin kesehatan keluarga.

e. Memanfaakan fasilitas pelayanan kesehatan disekitarnya bagi keluarga (Suprajitno, 2004 : hal 17-18)

6. Tahap-Tahap Kehidupan Keluarga

Tahap-tahap kehidupan keluarga menurut Duvall adalah sebagai berikut:

a. Tahap pembentukan keluarga Tahap ini dimulai dari pernikahan, yang dilanjutkan dalam bentuk rumah tangga.

b. Tahap menjelang kelahiran anak

c. Tugas keluarga yang utama untuk mendapatkan keturunan sebagai generasi penerus, melahirkan anak merupakan kebanggaan bagi ke!uarga yang merupakan saat-saat yang sangat dinantikan

d. Tahap menghadapi bayi

Dalam hal ini keluarga mengasuh, mendidik dan memberikan kasih sayang kepada anak, karena pada tahap ini bayi kehidupannya sangat tergantung kepada kedua orang tuanya. Dan kondisinya masih sangat lemah.

e. Tahap menghadapi anak pra-sekolah Anak sudah mulai mengenal kehidupan sosialnya, sudah mulai bergaul dengan teman sebaya, tetapi sangat rawan dalam masalah kesehatan, karena tidak mengetahui mana yang kotor dan mana yang bersih. Dalam fase ini anak sangat sensitif terhadap pengaruh lingkungan dan tugas keluarga adalah mulai rnenanamkan norma-norma agama, norma-norma sosial, budaya dan sebagainya.

f. Tahap menghadapi anak sekolah Bagaimana mendidik anak, mengajari anak untuk mempersiapkan masa depannya, membiasakan anak belajar 
secara teratur, mengontrol tugas-tugas sekolah anak dan meningkatkan pengetahuan umum anak.

Tahap menghadapi anak remaja

Tahap ini adalah tahap yang paling rawan, karena dalam tahap ini anak akan mencari identitas diri dalam membentuk kepribadiannya, oleh karena itu tauladan dari orang tua sangat diperlukan. Komunikasi dan saling pengertian antara kedua orang tua dengan anak perlu dipelihara dan dikembangkan.

g. Tahap melepaskan anak ke masyarakat Setelah melalui tahap rernaja dan anak telah dapat menyelesaikan pendidikannya, maka tahap selanjutnya adalah melepaskan anak ke masyarakat dalam memulai kehidupannya yang sesungguhnya, dalam tahap ini anak akan memulai kehidupan berumah tangga.

h. Tahap berdua kembali

Setelah anak besar dan menempuh kehidupan keluarga sendiri-sendiri, tinggallah suami istri berdua saja. Dalam tahap ini keluarga akan merasa sepi, dan bila tidak dapat menerima kenyataan akan dapat menimbulkan defresi dan stress.

i. Tahap masa tua

Tahap ini masuk ke tahap lanjut usia, dan kedua orang tua mempersiapkan diri untuk meninggalkan dunia fanah ini.

(Nasrul Effendi.1998, Hal 36-37)

Dalam siklus kehidupan setiap terdapat tahap-tahap yang dapat di prediksi formulasi tahap-tahap perkembangan kehidupan keluarga yang paling banyak digunakan untuk keluarga inti dengan dua orang tua adalah delapan tahap siklus kehidupan keluarga dan DuvalI yaitu:

a. Tahap I : Keluarga pemula (juga menunjuk pasangan menikah atau tahap pernikahan).

b.Tahap II : Keluarga sedang mengasuh anak (anak tertua adalah bayi sampai umur 30 bulan).

c. Tahap III Keluarga dengan anak usia pra sekolah (anak tertua berumur 2 hingga 6 tahun).

d.Tahap IV : Keluarga dengan anak usia sekolah (anak tertua berumur 6 hingga 13 tahun).

e.Tahap V : Keluarga dengan anak remaja (anak tertua berumur 13 hingga 20 tahun ).

f. Tahap VI : Keluarga yang melepas anak usia dewasa muda (mencakup anak pertama sampai anak terakhir yang meninggalkan rumah).
g.Tahap VII : Orang tua usia pertengahan (tanpa jabatan, pensiun).

h.Tahap VIII : Keluarga dalam masa pensiun dan lansia (juga menunjuk kepada anggota keluarga yang berusia lanjut atau pensiun hingga pasangan yang sudah meninggal dunia ).

(Marlyn M. fredman, 1998, Hal 113134).

\section{Tugas-Tugas Keluarga}

Pada dasarnya tugas keluarga ada 8 tugas pokok sebagai berikut:

a.Pemeliharaan fisik keluarga dan para anggotanya

b. Pemeliharaan sumber-sumber daya yang ada dalam keluarga

c. Pembagian tugas masing-masing anggotanya sesuai dengan kedudukannya masing-masing

d. Sosialisasi antar anggota keluarga

e. Pengaturan jumlah anggota keluarga

f. Pemeliharaan ketertiban anggota keluarga

g. Penempatan anggota-anggota keluarga dalam masyarakat yang Iebih luas

h. Memberikan dorongan dan semangat para anggota keluarga

(Nasrul Effendi, 1998, Hal 37).

\section{Proses Keperawatan Keluarga}

1. Pengertian

Proses keperawatan adalah kerangka kerja dalam melaksanakan tindakan yang diberikan kepada keluarga agar proses pertolongan yang diberikan kepada keluarga menjadi sistematis. Sekumpulan tindakan yang dipilih secara matang dalam usaha memperbaiki status kesehatan keluarga serta menambah kemampuan mereka dalam menyatakan masalah kesehatannya (S.G Baylon, 1978)

Proses keperawatan adalah metode ilmiah yang digunakan secara sistematis untuk mengurangi dan menentukan masalah kesehatan dan keperawatan, intervensi keperawatan keluarga sesuai dengan rencana yang telah disusun dan mengevaluasi mutu dari hasil asuhan keperawatan yang telah dilaksanakan terhadap keluarga.

2. Tahap-Tahap Proses Keperawatan

Tahap-tahap dalam proses keperawatan saling berhubungan antara satu dengan yang lainnya dan bersifat dinamis, dan disusun secara sistematis untuk menggambarkan perkembangan dari tahap yang satu ke tahap yang lain.

Adapun tahap tahap proses keperawatan adalah sebagai berikut : 
a. Tahap Pengkajian

Pengkajian perawatan menurut Salvison G. Baylon dan Arceillis Maglaya adalah sekumpulan tindakan yang digunakan oleh perawat untuk mengukur keadaan pasien dan keluarga dengan menggunakan norma-norma kesehatan pribadi maupun social system integritas dan kesanggupan untuk mengoreksi masalah-masalah. Yang termasuk dalam tahap ini adalah :

1) Tahapan pengkajian terdiri dari :

a) Pengumpulan data umum

Pengumpulan data dapat dilakukan melalui cara :

(1) Wawancara yang berkaitan dengan hal-hal yang perlu diketahui baik aspek fisik, mental, social budaya, ekonomi, kebiasaan, lingkungan dan sebagainya.

(2) Pengamatan observasi

(3) Studi dokumentasi misalnya yang berkaitan dengan perkembangan kesehatan diantaranya KMS, kartu kuning dan catatan kesehatan lainnya

(4) Pemeriksaan fisik pada seluruh anggota keluarga, tetapi digunakan pada anggota keluarga yang mempunyai masalah kesehatan berkaitan dengan keadaan kulit, turgor kulit dan pemeriksaan tubuh lainnya untuk mendeteksi adanya kelainan atau tanda-tanda munculnya penyakit.

b) Data-data yang perlu dikumpulkan meliputi :

(1) Identitas keluarga :

- Nama kepala keluarga ( KK )

- Alamat

- Pekerjaan KK

- Pendidikan KK

- Komposisi keluarga dan genogram

- Tipe keluarga

- Suku bangsa

- Agama

- Status social ekonomi keluarga

- Aktivitas rekreasi keluarga

(2) Riwayat dan perkembangan keluarga
- Tahap perkembangan keluarga saat ini

- Tahap perkembangan keluarga yang belum terpenuhi

- Riwayat keluarga inti

- Riwayat keluarga sebelumnya

(3) Pengkajian lingkungan

- Karakteristik rumah

- Karakteristik dan komunitas tetangga

- Mobilitas geografis keluarga

- Perkumpulan keluarga dan interaksi dengan masyarakat

- Sistem pendukung keluarga

(4) Struktur keluarga

- Pola komunikasi dalam keluarga

- Struktur kekuatan keluarga

- Struktur peran

- Nilai atau norma keluarga

(5) Fungsi keluarga

- Fungsi afektif

- Fungsi sosialisasi

- Fungsi perawatan keluarga

- Fungsi reproduksi

- Fungsi ekonomi

(6) Stress dan koping keluarga

- Stressor jangka pendek dan panjang

- Kemampuan keluarga berespon terhadap situasi/stressor

- Strategi adaptasi disfungsionalis

(7) Pemeriksaan fisik

(8) Harapan keluarga

\section{Analisa Data}

Dalam mengambil data ada 3 hal yang harus diperhatikan dalam melihat perkembangan kesehatan keluarga yaitu :

a. Keadaan kesehatan normal dari setiap anggota keluarga

1) Keadaan kesehatan fisik, mental,social anggota keluarga

2) Keadaan pertumbuhan dan perkembangan anggota keluarga

b. Keadaan rumah dan situasi lingkungan

1) Rumah meliputi ventilasi, penerangan, kebersihan, luas rumah, dan pemanfaatan pekarangan yang ada.

2) Sumber air minum 
3) Jamban keluarga

4) Tempat pembuangan limbah

c. Karakteristik Pekarangan

1) Sifat keluarga

2) Dinamika dalam keluarga

3) Interaksi antar anggota keluarga

4) Kesanggupan keluarga dalam membawa perkembangan anggota keluarga

5) Kebiasaan dan nilai-nilai yang berlaku dalam keluarga

\section{Diagnosa Keperawatan Keluarga}

Setelah data dianalisa, maka selanjutnya dapat dirumuskan diagnosa keperawatan keluarga. Perawatan selalu mengacu pada tipologi dan kesehatan keperawatan.

a. Aktual (terjadi deficit/gangguan kesehatan) Diagnosa keperawatan actual dapat ditentukan jika pada pengkajian didapatkan data mengenai tanda dan gejala dari gangguan kesehatan.

b. Resiko (ancaman kesehatan)

Resiko dapat ditetapkan jika ada data yang menunjang, namun bukan terjadi gangguan misalnya : lingkungan rumah yang kurang bersih, pola makan yang tidak adekuat, stimulasi tumbuh kembang yang tidak adekuat.

c. Potensial (keadaan sejahtera)

Potensial dapat ditentukan jika keadaan keluarga sejahtera sehingga kesehatan lingkungan dapat ditingkatkan.

Adapun diagnosa keperawatan keluarga yang dapat muncul dalm melaksanakan tugas-tugas keperawatan yaitu :

a. Ketidaksanggupan mengenai masalah kesehatan keluarga disebabkan karena:

1) Kurang pengetahuan/ketidaktahuan fakta

2) Sikap dan falsafah hidup

b. Ketidaksanggupan keluarga mengambil keputusan dalam mengambil tindakan yang tepat karena :

1) Tidak memahami sifat, berat dan luasnya masalah

2) Masalah kesehatan tidak begitu menonjol

c. Ketidakmampuan merawat anggota keluarga yang sakit disebabkan karena :

1) Tidak memahami mengenai sifat, berat dan luasnya masalah

2) Sikap dan pandangan hidup

d. Ketidakmampuan memelihara lingkungan rumah yang dapat mempengaruhi kesehatan dan perkembangan pribadi yang disebabkan karena :

1) Ketidaktahuan tentang pentingnya sanitasi lingkungan

2) Sikap dan pandangan hidup

e. Ketidakmampuan menggunakan sumber

di masyarakat guna memelihara kesehatan disebabkan karena :
1) Tidak memahami keuntungan yang diperoleh

2) Tidak terjangkaunya fasilitas yang memadai

Tabel 2.1 Prioritas Masalah/Skala Penyusunan Masalah Kesehatan Keluarga

\begin{tabular}{|c|c|c|c|}
\hline NO & Kriteria & Nilai & Bobot \\
\hline \multirow[t]{4}{*}{1} & Sifat masalah & & 1 \\
\hline & a. Ancaman & 2 & \\
\hline & Kesehatan & 3 & \\
\hline & b. Tidak/kurang & 1 & \\
\hline \multirow[t]{4}{*}{2} & sehat & & 2 \\
\hline & c. Krisis & 2 & \\
\hline & Kemungkinan & 1 & \\
\hline & masalah dapat & 0 & \\
\hline \multirow[t]{4}{*}{3} & diubah,skala & & 1 \\
\hline & a. Mudah & 3 & \\
\hline & b. Hanya sebagian & 2 & \\
\hline & c. Tidak dapat & 1 & \\
\hline \multirow[t]{14}{*}{4} & Potensi masalah & & 1 \\
\hline & dapat diubah & 2 & \\
\hline & a. Tinggi & 1 & \\
\hline & b. Cukup & & \\
\hline & c. Rendah & 0 & \\
\hline & Menonjolnya & & \\
\hline & masalah,skala : & & \\
\hline & a. Masalah berat & & \\
\hline & $\begin{array}{ll}\text { harus } & \text { segera }\end{array}$ & & \\
\hline & $\begin{array}{l}\text { ditangani } \\
\text { b. Masalah yang }\end{array}$ & & \\
\hline & tak perlu segera & & \\
\hline & ditangani & & \\
\hline & c. Masalah tidak & & \\
\hline & dirasakan & & \\
\hline
\end{tabular}

Sumber :

Nasrul Effendy, Jakarta, 1998.

Dasar-Dasar Keperawatan

Kesehatan Masyarakat

\section{Tinjauan Teori}

TB Paru adalah penyakit infeksi menular, yang terutama menyerang perenkim paru. Tuberculosis dapat juga ditularkan ke bagian tubuh lainnya, termasuk meningens, ginjal, tulang dan nodus limfe.( Suzanne C. Smeltzer \& Brenda G. Bare, 2001)

\section{Anatomi Fisiologi}

Anatomi Saluran Pernafasan

Saluran pernafasan dimulai dari hidung, nasofaring, mulut, orofaring, laring, trachea, bronkhus kiri dan kanan, bronkhiolus dan alveolus.Paru- paru merupakan organ yang elastis, berbentuk kerucut dan letaknya di dalam rongga dada atau thoraks kedua paru saling terpisah oleh mediastinum sentral yang berisi jantung dan beberapa pembuluh darah besar. Paru kanan lebih besar dari paru kiri. 
a. Fisiologi

Tujuan utama pernapasan adalah menyediakan oksigen bagi seluruh jaringan tubuh dan mengeluarkan karbondioksida dari dalam tubuh. Udara didistribusikan ke dalam paru melaui trachea, bronchus dan bronchiolus. Trachea disebut generasi pertama saluran napas,dan dua bronchus kiri kanan adalah generasi kedua, tiaptiap bagian sesudah itu di sebut generasi tambahan.

Bila udara melalui hidung akan ada tiga fungsi tertentu yang di perankan oleh hidung :

1) Udara dihangatkan oleh permukaan konka dan septum hidung yang luasnya kira-kira $160 \mathrm{~m}^{2}$.

2) Udara dilembabkan sampai hampir lembab sempurna sebelum udara meninggalkan hidung.

3) Udara disaring. Bulu-bulu pada pintu masuk hidung penting untuk penyaringan partikel besar.

Mekanisme penyaringan hidung untuk mengeluarkan partikel dari udara begitu efektif, sehingga tidak ada partikel yang berukuran > 6 mikron meter yang dapat masuk ke dalam paru (ukuran ini lebih kecil dari ukuran sel darah merah). Setelah udara tiba di alveoli langkah selanjutnya dalam pernapasan adalah difusi oksigen dari alveoli ke pembuluh darah. Proses difusi berlangsung sederhana meliputi gerakan molekul-molekul secara bebas dan acak. Dinding alveolus sangat tipis dan didalamnya terdapat jaringan kapiler yang hampir padat dan saling berhubungan. Dengan demikian,jelas bahwa gas alveoli berada sangat dekat dengan darah kapiler. Akibatnya, pertukaran gas antara udara alveoli dan darah paru menjadi lebih mudah dan cepat.

Setelah oksigen berdifusi kedalam darah, terjadi pengikatan oksigen oleh eritrosit melalui ikatan kimiawi dengan haemoglobin.Selanjutnya bersirkulasi mengikuti peredaran darah ke jaringan untuk dipakai oleh sel. Pada saat oksigen dipakai oleh sel ini menjadi karbondioksida, sehingga $\mathrm{PCO}_{2}$ meningkat, oleh karena itu karbondioksida berdifusi dari sel ke kapiler untuk dibawa keparu dan selanjutnya dikeluarkan dari dalam tubuh.

\section{Etiologi}

Penyebab tuberkulosis adalah

mycobacterium tuberculosis merupakan sejenis kuman berbentuk batang dengan ukuran panjang $1-4$ /um dan tebal 0,3-0,6 /um. Sebagian besar kuman terdiri dari asam lemak (lipid). Lipid ini yang membuat kuman lebih tahan lama terhadap gangguan kimia dan fisik. Kuman dapat tahan hidup pada waktu udara kering maupun keadaan dingin. Di dalam jaringan, kuman hidup sebagai parasit intra celuler yakni dalam sitoplasma makrofag. Sifat lain kuman ini adalah aerob. Seperti ini menunjukkan bahwa kuman lebih menyenangi jaringan yang tinggi oksigennya.

\section{Masa inkubasi}

Masa inkubasi 4-6 minggu.

\section{Tanda dan Gejala}

Keluhan yang dirasakan penderita tuberkulosis dapat bermacam-macam atau malah tanpa keluhan sama sekali. Keluhan yang terbanyak adalah :

a.Demam

Biasanya subfebril menyerupai demam influenza. Tapi kadang-kadang panas badan dapat mencapai $40-41{ }^{\circ} \mathrm{C}$ serangan demam pertama dapat sembuh kembali. Begitu pula terus menerus hilang timbulnya demam influenza ini sehingga penderita merasa tidak pernah terbebas dari serangan demam Influenza. Keadaan ini sangat dipengaruhi daya tahan tubuh penderita dan berat ringannya infeksi kuman tuberkulosis yang masuk.

b.Batuk

Gejala ini banyak ditemukan batuk terjadi karena adanya iritasi pada bronchus. Batuk ini diperlukan untuk membuang produk-produk radang keluar. Karena terlihatnya bronchus pada penyakit tidak sama.

Sifat batuk ini dimulai dari batuk kering/nonproduktif kemudian timbul peradangan dan menjadi batuk produktif. Keadaan lanjut berupa batuk darah atau haemoptoe karena terdapat pembuluh darah vena. Kebanyakan batuk darah terjadi pada kavitas tetapi juga terjadi pada dinding bronhus.

c. Sesak nafas

Pada awal serangan sesak nafas belum dirasakan, dan akan timbul pada penyakit yang usia lanjut karena infiltrasi sudah setengah bagian paru.

d.Nyeri dada

Gejala ini jarang ditemukan dan timbul bila infiltrasi sudah sampai ke pleura sehingga menimbulkan pleuritis.

e.Malaise

Gejala ini sering ditemukan berupa : tidak ada nafsu makan, sakit kepala, meriang, nyeri otot, keringat malam, dan lain-lain. Gejala ini makin lama makin berat dan terjadi hilang timbul secara teratur. 


\section{Patogenesis}

Tempat masuk kuman $M$. tuberculosis adalah saluran pernapasan, saluran pencernaan, dan luka terbuka pada kulit. Kebanyakan infeksi tuberkulosis terjadi melalui udara (airborne), yaitu melalui inhalasi droplet yang mengandung kuman-kuman basil tuberkel yang berasal dari orang-orang terinfeksi. Saluran pencernaan merupakan tempat masuk utama bagi jenis bovin, yang penyebarannya melalui susu yang terkontaminasi. Akan tetapi di Amerika Serikat, dengan luasnya pasteurisasi susu dan deteksi penyakit pada sapi perah, tuberkulosis bovin ini jarang terjadi.

Tuberkulosis adalah penyakit yang dikendalikan oleh respon imunitas perantara sel. Sel efektornya adalah makrofag, sedangkan limfosit (biasanya sel T) adalah sel imunoresponsifnya. Tipe imunitas seperti ini biasanya lokal, melibatkan makrofag yang diaktifkan di tempat infeksi oleh limfosit dan limfokinnya. Respon ini disebut sebagai reaksi hipersensitivitas.

Basil tuberkel yang mencapai permukaan alveolus biasanya diinhalasi sebagai suatu unit yang terdiri dari satu sampai tiga basil; gumpalan basil yang lebih besar cenderung tertahan di saluran hidung dan cabang besar bronkus dan tidak menyebabkan penyakit (Dannenberg, 1981). Setelah berada dalam ruang alveolusbiasanya dibagian bawah lobus atas paruparu atau dibagian atas lobus bawah-basil tuberkel ini membangkitkan reaksi peradangan. Leukosit polimorfonuklear tampak pada tempat tersebut dan memfagosit bakteri namun tidak membunuh organisme tersebut. sesudah hari pertama maka leukosit diganti oleh makrofag. Alveoli yang terserang akan mengalami konsolidasi dan timbul gejala pneumonia akut. Pneumonia selular ini dapat sembuh dengan sendirinya, sehingga tidak ada sisa yang tertinggal, atau proses dapat juga berjalan terus, dan bakteri terus difagosit atau berkembang biak di dalam sel. Basil juga menyebar melalui getah bening menuju ke kelenjar getah bening regional. Makrofag yang mengadakan infiltrasi menjadi lebih panjang dan sebagian bersatu sehingga membentuk sel tuberkel epiteloid, yang dikelilingi limfosit. Reaksi ini biasanya membutuhkan waktu 10 sampai 20 hari.

Nekrosis bagian sentral lesi memberikan gambaran yang relatif padat dan seperti keju, lesi nekrosis ini disebut nekrosis kaseosa. Daerah yang mengalami nekroses kaseosa dan jaringan granulasi di sekitarnya yang terdiri dari sel epiteloid dan fibroblas, menimbulkan respon berbeda. Jaringan granulasi menjadi lebih fibrosa, membentuk jaringan parut yang akhirnya akan membentuk suatu kapsul yang mengelilingi tuberkel.

Lesi primer paru-paru dinamakan fokus Ghon dan gabungan terserangnya kelenjar getah bening regional dan lesi primer dinamakan kompleks Ghon. Kompleks Ghon yang mengalami perkapuran ini dapat dilihat pada orang sehat yang kebetulan menjalani pemeriksaan radiogram rutin.

Respon lain yang dapat terjadi pada daerah nekrosis adalah pencairan, dimana bahan cair lepas ke dalam bronkus dan menimbulkan kavitas. Materi tuberkular yang dilepaskan dari dinding kavitas akan masuk ke dalam percabangan trakeobronkial. Proses ini dapat akan terulang kembali di bagian lain dari paruparu, atau basil dapat terbawa sampai ke laring, telinga tengah atau usus.

Kavitas yang kecil dapat menutup sekalipun tanpa pengobatan dan meninggalkan jaringan parut fibrosa. Bila peradangan mereda lumen bronkus dapat menyempit dan tertutup oleh jaringan parut yang terdapat dekat dengan perbatasan bronkus rongga. Bahan perkijuan dapat mengental sehingga tidak dapat mengalir melalui saluran penghubung, sehingga kavitas penuh dengan bahan perkijuan, dan lesi mirip dengan lesi berkapsul yang tidak terlepas. Keadaan ini dapat tidak menimbulkan gejala dalam waktu lama atau membentuk lagi hubungan dengan bronkus dan menjadi tempat peradangan aktif.

Penyakit dapat menyebar melalui getah bening atau pembuluh darah. Organisme yang lolos dari kelenjar getah bening akan mencapai aliran darah dalam jumlah kecil, yang kadang - kadang dapat menimbulkan lesi pada berbagai organ lain. Jenis penyebaran ini dikenal sebagai penyebaran limfhohematogen, yang biasanya sembuh sendiri. Penyebaran hematogen merupakan suatu fenomena akut yang biasanya menyebabkan tuberkulosis milier. Ini terjadi apabila fokus nekrotik merusak pembuluh darah sehingga banyak organisme masuk ke dalam sistem vaskular dan tersebar ke organ-organ tubuh.

\section{Cara penularan}

Sumber penularan adalah penderita TB paru BTA Positif. Pada waktu batuk atau bersin, penderita menyebarkan 
kuman ke udara dalam bentuk droplet (percikan dahak). Droplet yang mengandung kuman dapat bertahan di udara bebas selama beberapa jam, tergantung ada tidaknya sinar ultraviolet, ventilasi yang buruk dan kelembaban.

Dalam suasana lembab dan gelap kuman dapat tahan berhari - hari sampai berbulan-bulan. Orang dapat terinfeksi kalau droplet tersebut terhirup ke dalam saluran pernafasan.

Daya penularan dari seorang penderita ditentukan oleh banyaknya kuman yang dikeluarkan dari parunya. Makin tinggi derajat positif hasil pemeriksaan dahak, makin menular penderita tersebut. Bila hasil pemeriksaan negatif, maka penderita tersebut dianggap tidak menular. Kemungkinan seseorang terinfeksi TB ditentukan oleh konsentrasi droplet dalam udara dan lamanya menghirup udara tersebut.

\section{Pemeriksaan Diagnostik}

a. Pemeriksaan sputum : untuk mengetahui adanya biakan Mycobacterium TB.

b. Zichl Nielsen : untuk mengetahui bakteri tahan asam pada dahak menunjukkan hasil tahan asam positif.

c. Skin test/mantoux test terjadi reaksi positif bila terjadi reaksi positif yaitu indurasi lebih dari $10 \mathrm{~mm}$.

d. Foto rontgen : yaitu ditemukan bayangan lesi, terutama pada atas paru atau bayangan atau terdapat klasifikasi.

e. Biopsi tubuh : dimana nampak sel-sel raksasa yang menandakan terjadinya nekrose.

f. Pengukuran fungsi paru : terdapat penurunan kapasitas paru.

\section{Pencegahan dan Pengobatan}

\section{a.Pencegahan TBC Paru}

Pencegahan penyakit TBC sebaiknya tidak hanya bertumpu pada vaksinasi Bacillus Calmette Guirine (BCG), sebab vaksin $\mathrm{BCG}$ tak menjamin seseorang kebal terhadap kuman TBC, akan tetapi lebih efektif jika pencegahan TBC di integrasikan dalam konteks lingkungan sosial masyarakat.

b.Pengobatan

Obat anti tuberkulosa diberikan dalam bentuk kombinasi dari beberapa jenis, dalam jumlah cukup dan dosis tepat selama $6-8$ bulan. Supaya semua kuman (termasuk kuman persisten) dapat dibunuh. Jenis obat yang digunakan yaitu

1) Isoniasid $(\mathrm{H})$
Dikenal dengan INH, bersifat bakterisid, dapat membunuh $90 \%$ populasi kuman dalam beberapa hari pertama pengobatan. Dosis harian yang dianjurkan $5 \mathrm{mg} / \mathrm{kg} \quad \mathrm{BB}$. Sedangkan unutk pengobatan intermitten 3 kali seminggu diberikan dengan dosis $10 \mathrm{mg} / \mathrm{kg} \mathrm{BB}$.

2) Rifampisin $\AA$

Bersifat bakterisid, dapat membunuh kuman semidormant (persisten) yang tidak dapat dibunuh oleh isoniasid dosis $20 \mathrm{mg} / \mathrm{kg} \mathrm{BB}$, diberikan sama untuk pengobatan harian maupun intermitten 3 kali seminggu.

3) Pirasinamid $(Z)$

Bersifat bakterisid, dapat membunuh kuman yang berada dalam sel dengan suasana asam. Dosis harian yang dianjurkan 25 $\mathrm{mg} / \mathrm{kg} \quad \mathrm{BB}$, sedangkan untuk pengobatan intermitten 3 kali seminggu diberikan dengan dosis 35 $\mathrm{mg} / \mathrm{kg} \mathrm{BB}$

4) Streptomisin (S)

Bersifat bakterisid. Dosis harian yang dianjurkan $15 \mathrm{mg} / \mathrm{kg} \mathrm{BB}$, sedangkan untuk pengobatan intermitten 3 kali seminggu digunakan dosis yang sama.

5) Ethambul (E) Bersifat sebagai bakteristatik. Dosis harian yang dianjurkan 15 $\mathrm{mg} / \mathrm{kg} \quad \mathrm{BB}$ sedangkan untuk pengobatan intermitten 3 kali seminggu digunakan dosis $30 \mathrm{mg} / \mathrm{kg}$ BB.

(Arif Mansjoer,Kapita selekta kedokteran)

Panduan OAT di Indonesia yang merupakan rekomendasi dari WHO dan IUATLD (International Union Against Tuberculosis and Lung Disease), yaitu :

a. Kategori 1 (2HRZE/4H3R3) atau (2 Bulan 4FDC/4 Bulan 2 FDC)

Tahap intensif terdiri dari isoniasid, rifampisin, pirazinamid dan ethambutol, obat - obat tersebut diberikan setiap hari selama 2 bulan (2 HRZE). Kemudian diteruskan dengan tahap lanjutan yang terdiri dari isoniasid, rifampisin diberikan 3 kali seminggu selama 4 bulan (4H3R3).

Obat ini diberikan untuk :

1) Penderita baru TB Paru BTA Positif. 
2) Penderita TB Paru BTA negatif rontgen positif yang sakit berat.

3) Penderita TB ekstra paru berat.

Dosis pengobatan TB dengan tablet FDC berbeda dengan dosis kombipak. Dosis pengobatan dengan FDC diseuasuaikan dengan berat badan penderita sesuai dengan rekomendasi WHO dan IUALTD.

\section{b.Kategori 2 (2HRZES/HRZE/5H3R3E3)}

Tahap intensif diberikan selama 3 bulan, yang terdiri dari 2 bulan dengan isoniasid, rifampisin, pirasinamid, ethambutol dan suntikan streptomisin setiap hari di unit pelayanan kesehatan. Dilanjutkan 1 bulan dengan isoniasid, rifampisin dan pirasinamid dan ethambutol setiap hari. Setelah itu diteruskan dengan tahap lanjutan selama 5 bulan dengan HRE yang diberikan 3 kali seminggu.

Obat ini diberikan untuk :

$$
\begin{aligned}
& \text { 1) Penderita TB Paru BTA } \\
& \text { Positif kambuh. } \\
& \text { Penderita TB Paru BTA } \\
& \text { Positif gagal } \\
& \text { Penderita TB Paru setelah } \\
& \text { defaulter/setelah lalai yang kembali } \\
& \text { dengan hasil BTA positif. } \\
& \text { c.Kategori } 3
\end{aligned}
$$

Tahap intensif terdiri dari isoniasid, rifampiisin, pirasinamid di berikan setiap hari selama 2 bulan (2 HRZ). Diteruskan dengan tahap lampiran terdiri dari HR selama 4 bulan diberikan 3 kali seminggu (4H3R3).

Obat ini diberikan untuk :
1) Penderita baru BTA negatif dan rontgen positif sakit ringan.
2) Penderita ekstra paru ringan, yaitu TB kelenjar limfe, pleuritis eksudativa unilateral, TB kulit, TB tulang, sendi dan kelenjar adrenal.

\section{Perawatan}

a. Mencatat fungsi pernafasan : bunyi, irama, kedalaman.

b. Kemampuan mengeluarkan dahak, warna, jumlah, dan ada darah atau tidak.

c. Memberikan sikap fowler/semi fowler.

d. Memberikan oksigen lembab anak 0,5 $-2,5 \mathrm{l} / \mathrm{mnt}$, dan orang dewasa $3-15$ $1 / \mathrm{mnt}$.

e. Mencatat status gizi, turgor kulit, berat badan, kemampuan makan dan riwayat anoreksia. f. Memberikan istirahat yang cukup minimal 8 jam/hari.

g. Menyarankan untuk makan makanan yang berprotein tinggi dan kalori tinggi.

h. Mengenal resiko penularan pada anggota keluarga.

i. Menyarankan pada pasien bila batuk menutup mulut.

j. Menyarankan untuk tidak merokok.

k. Membuang ludah/dahak pada tempatnya yang berisi larutan disinfektan.

1. Menjelaskan pentingnya berobat secara adekuat.

m. Memantau pemeriksaan ulang dahak secara berkala.

\section{Asuhan Keperawatan TB Paru}

a. Pengkajian

1) Aktivitas/istirahat

Gejala :

a) Rasa lemah cepat lelah, aktivitas berat timbul.

b) Sesak (nafas pendek), sulit tidur, demam, menggigil, berkeringat pada malam hari.

Tanda :

a)Takikardia, takipnea/dispnea pada kerja.

b) Kelemahan otot, nyeri, dan sesak (tahap lanjut).

2) Integritas ego

Gejala :

a)Adanya/faktor stress lama.

b) Masalah keuangan, rumah.

c)Perasaan tak berdaya/tidak ada harapan.

Tanda :

a)Menyangkal (khususnya selama tahap dini).

b) Ansietas, ketakutan, mudah terangsang.

3) Makanan/cairan

Gejala :

a)Kehilangan nafsu makan

b) Tidak dapat mencerna.

c)Penurunan berat badan.

Tanda :

a)Turgor kulit buruk, keringat/kulit bersisik.

b) Kehilangan otot/hilang lemak subkutan.

4) Nyeri/Kenyamanan

Gejala :

Nyeri dada meningkat karena batuk yang berulang.

Tanda :

a)Berhati-hati pada area yang sakit.

b) Prilaku distraksi, gelisah. 
5) Pernapasan

Gejala :

a)Batuk, produktif atau tidak produktif.

b) Nafas pendek.

c)Riwayat tuberkulosis/terpajan pada individu terinfeksi.

Tanda :

a)Peningkatan frekuensi pernafasan (penyakit).

b) Luas atau fibrosis parenkim paru dan pleura.

c)Perkusi pekak dan penurunan fremitus (cairan pleura atau penebalan pleura).

d) Bunyi nafas menurun/tidak ada secara bilateral atau unilateral (efusi pleura/paru motorik).

e)Bunyi nafas tubuler dan/atau bisikan pektoral di atas lesi luas.

f) Krekels tercatat di atas apex paru selama inspirasi cepat setelah batuk pendek (krekels posttusisic).

g) Karakteristik sputum : hijau/purulen, mukoid kuning, atau bercak darah.

h) Deviasi trachea (penyebaran berkogenik).

i) Tak perhatian, mudah terangsang yang nyata, perubahan mental (tahap lanjut).

6) Keamanan

Gejala :

a)Adanya kondisi penekanan imun, contoh AIDS, kanker.

b) Tes HIV positif.

Tanda :

Demam rendah atau sakit panas diet.

7) Interaksi sosial

Gejala :

a)Perasaan isolasi/penolakan karena penyakit menular.

b) Perubahan pola biasa dalam tanggung jawab/perubahan kapasitas fisik untuk melaksanakan peran.

8) Penyuluhan/pembelajaran

Gejala :

a)Riwayat keluarga TB.

b) Ketidakmampuan / status kesehatan buruk.

c)Gejala untuk membaik/kambuhnya TB.

d) Tidak berpartisipasi dalam terapi.

Rencana pemulangan :

Memerlukan bantuan dengan gangguan dalam terapi obat dan perawatan diri dan pemeliharaan/perawatan diri dan pemeliharaan/ perawatan rumah.

9) Pemeriksaan diagnostik

a)Kultur sputum : positif untuk mikobakterium tuberculosis pada tahap aktif penyakit.

b) Ziehl- neelsen (pemakaian asam cepat pada gelas kaca untuk usapan cairan darah) : positif untuk basil asam - cepat.

c)Reaksi bermakna pada pasien yang secara nyata klinik, sakit, berarti bahwa TB aktif tidak dapat diturunkan atau infeksi disebabkan oleh mikobakterium yang berbeda.

d) Elisa/western blot :

e)Foto thorax :

f) Histologi/kultur jaringan paru (termasuk pembersihan)

g) Elektrolit : dapat tak normal tergantung pada lokasi dan beratnya infeksi.

h) Gas darah arteri : dapat normal tergantung lokasi, berat, dan kerusakan sisa pada paru.

i) Pemeriksaan fungsi paru : penurunan kapasitas vital. Peningkatan ruang mati, peningkatan rasio udara residu atau kapasitas paru total, dan penurunan saturasi oksigen sekunder terhadap infiltrasi parenkim/fibrosis, kehilangan jaringan paru dan penyakit pleural (TB paru kronis luas).

b. Prioritas Keperawatan

1) Meningkatkan/mempertahankan ventilasi (oksigenasi adekuat).

2) Mencegah penyebaran infeksi.

3) Mendukung prilaku/tugas untuk mempertahankan kesehatan.

4) Meningkatkan strategi koping efektif.

5) Merupakan informasi tentang proses penyakit/prognosis dan kebutuhan pengobatan.

Tujuan pemulangan

1) Fungsi pernafasan adekuat untuk memenuhi kebutuhan individual.

2) Komplikasi dicegah.

3) Pola hidup/prilaku berubah diadopsi untuk mencegah penyebaran infeksi.

4) Proses penyakit/prognosis dan program pengobatan dipahami. 
Diagnosa Keperawatan

1) Infeksi, resiko tinggi (penyebaran/aktivasi ulang)

Faktor resiko meliputi :

a) Pertahanan primer tidak adekuat, penurunan kerja silia/statis sekret.

b) Kerusakan jaringan/tambahan infeksi.

c) Penurunan pertahanan/penekanan proses inflamasi.

d) Malnutrisi.

e) Terpajan lingkungan.

f) Kurang pengetahuan untuk menghindari penajaman patogen.

Kemungkinan dibuktikan oleh :

Tidak dapat diterapkan ; adanya tanda-tanda dan gejala-gejala membuat diagnosa aktual.

2) Bersihkan jalan nafas, tak efekfif. Dapat dihubungkan dengan :

a) Sekret kental, atau sekret darah.

b) Kelemahan, upaya batuk buruk.

c) Edema trakeal/faringeal.

Kemungkinan dibuktikan oleh :

a) Frekuensi pernafasan, irama, kedalaman tak normal.

b) Bunyi nafas tak normal (ronkhi, Mengi), stridor.

c) Dispnea.

3) Pertukaran gas, kerusakan, resiko tinggi terhadap faktor resiko meliputi :

Faktor resiko meliputi :

a) Penurunan permukaan efektif paru, atelektasis.

b) Kerusakan membran alveolus kapiler.

c) Sekresi kental, tebal.

d) Edema bronkial.

Kemungkinan dibuktikan oleh :

Tidak dapat diterapkan ; adanya tanda-tanda dan gejala-gejala membuat diagnosa aktual.

4) Nutrisi, perubahan, kurang dari kebutuhan tubuh.

Dapat dihubungkan dengan :

a) Kelemahan.

b) Sering batuk/produksi sputum, dispnea.

c) Anorexia

d) Ketidakcukupan sumber keuangan.

Kemungkinan dibuktikan oleh :

a) Berat badan di bawah $10 \%-20$ $\%$ idal untuk bentuk tubuh dan berat. b) Melaporkan kurang tertarik pada makanan, gangguan sensasi pengecap.

c) Tonus otot buruk.

5) Kurang pengetahuan (kebutuhan belajar) mengenai kondisi, aturan tindakan, dan pencegahan.

Dapat dihubungkan dengan :

a) Kurang terpajan/salah interpretasi informasi.

b) Keterbatasan kognitif.

c) Tak akurat/tak lengkap informasi yang ada.

Kemungkinan dibuktikan oleh :

a) Permintaan informasi.

b) Menunjukkan kesalahan konsep tentang status kesehatan.

c) Kurang atau tak akurat mengikuti instruksi/prilaku.

d) Mewujudkan atau memperlihatkan perasaan terancam.

c. Perencanaan

1) Diagnosa - keperawatan 1 (infeksi, resiko tinggi (penyebaran/aktif ulang).

Mandiri :

a)Kaji patologi penyakit (aktif/fase tak aktif) ; diseminasi infeksi melalui bronchus untuk membatasi jaringan atau melalui aliran darah/sistem limpatik) dan potensial penyebaran infeksi melalui droplet udara selama batuk, bersin, meludah, bicara, tertawa, menyanyi.

Rasional :

Membantu pasien

menyadari/menerima perlunya mematuhi program pengobatan untuk mencegah pengaktifan berulang/ komplikasi

disebarkan, pemahaman bagaimana penyakit disebarkan dan kesadaran kemungkinan membantu pasien/orang terdekat untuk mengambil langkah untuk mencegah infeksi ke orang lain.

b) Identifikasi orang lain yang beresiko, contoh : anggota rumah, sahabat karib/teman.

Rasional :

Orang-orang yang terpajan ini perlu program terapi obat untuk mencegah penyebaran/terjadinya infeksi.

c) Anjurkan pasien untuk batuk/bersin dan mengeluarkan pada tissu dan menghindari meludah. Kaji pembuangan 
tissu sekali pakai dan tehnik mencuci tangan yang tepat dorong untuk mengulangi demonstrasi.

Rasional :

Prilaku yang diperlukan untuk mencegah penyebaran infeksi.

d) Kaji tindakan kontrol infeksi sementara, contoh masker atau isolasi pernafasan.

Rasional :

Dapat membantu menurunkan rasa terisolasi pasien dan membuang stigma sosial sehubungan dengan penyakit menular.

e) Awasi suhu sesuai indikasi. Rasional :

Reaksi deman indikator adanya infeksi lanjut.

f) Identifikasi adanya fraktur resiko individu terhadap pengaktivan berulang tuberkulosis, contoh : tahanan awan (alkoholisme, malnutrisi) gunakan obat penekanan urmur/kortikosteroid.

Rasional :

Pengetahuan tentang faktor ini membantu pasien untuk mengubah pola hidup dan menghindari/menurunkan insiden

g) Tekankan pentingnya tidak menghentikan terapi obat.

Rasional :

Periode singkat berakhir $2-3$ hari setelah kemoterapi awal, tetapi pada adanya penyakit luas, resiko penyebaran infeksi dapat berlanjut sampai 3 bulan.

h) Kaji pentingnya mengikuti kultur ulang secara periodik terhadap sputum untuk lamanya terapi.

Rasional :

Alat dalam pengawasan efek dan keefektifan obat dan respon pasien terhadap terapi.

2) Diagnosa keperawatan 2 : Bersihan jalan nafas tidak efektif :

Tindakan/intervensi :

Mandiri:

a) Kaji fungsi pernafasan, contoh : bunyi nafas, kecepatan irama dan penggunaan aksesoris.
Rasional :

Penurunan bunyi nafas dapat menunjukkan atelektasis.

Ronchi mengi menunjukkan akumulasi

sekret/ketidakmampuan untuk membersihkan jalan nafas dan peningkatan kerja pernafasan.

b) Catat kemampuan untuk mengeluarkan mukosa/batuk efektif.

Catat karakter jumlah sputum, adanya hemoptoe

Rasional :

Pengeluaran sulit bila sekret sangat tebal. Sputum berdarah kental atau berdarah cerah diakibatkan oleh kerusakan kavitas paru atau luka bronchial dan dapat memerlukan evaluasi/intervensi lanjut.

c) Berikan pasien posisi semi fowler tinggi, bantu pasien untuk batuk dan latihan nafas dalam

Rasional :

Posisi membantu memaksimalkan ekspansi paru dan menurunkan upaya pernapasan. Ventilasi maksimal membuka area atelektasi dan meningkatkan gerakan sekret ke dalam jalan nafas besar untuk dikeluarkan.

d) Bersihkan sekret dari mulut dan trakhea ; penghisapan sesuai dengan keperluan

Rasional :

Mencegah obstruksi/aspirasi. Penghisapan dapat diperlukan bila pasien tanpa mengeluarkan sekret.

e) Pertahankan masukan cairan sedikitnya $2500 \mathrm{ml} /$ hari kecuali kontra indikasi.

Rasional :

Pemasukan tinggi cairan membantu untuk mengencerkan sekret, membuatnya mudah keluar.

Kolaborasi :

Lembabkan udara/oksigen inspirasi.

Rasional :

Mencegah penyaringan membran mukosa, membantu pengenceran sekret.

f) Beri obat-obat sesuai dengan indikasi. 
Seperti mukolitik, contoh asetilis sistem (mucomysys)

Rasional :

- Agar mukolitik menurunkan kekentalan dan perlengkatan sekret paru untuk memudahkan pembersihan.

- Kortikosteroid (prednison).

Rasional :

Berguna pada adanya

keterlibatan luas dengan

hipoksemia dan bila respons

inflamasi mengancam hidup.

3) Diagnosa keperawatan 3 ; pertukaran gas, kerusakan, resiko tinggi terhadap :

Tindakan/intervensi :

Mandiri :

a) Kaji dispnea, takipnea, tak normal/menurunnya bunyi nafas, peningkatan upaya pernafasan, terbatasnya ekspansi dinding dada, dan kelemahan.

Rasional :

TB paru menyebabkan efek luas pada paru dan bagian kecil bronkopneumonia sampai inflamasi difus luas, nekrosis, effusi pleura, dan fibrosa luas, efek pernafasan dapat dari ringan sampai dispnea berat sampai distres pernafasan.

b) Evaluasi perubahan pada tingkat kesadaran, catata sianosis dan/atau perubahan pada warna kulit, termasuk membran mukosa dan kuku.

Rasional :

Akumulasi sekret/pengaruh jalan nafas dapat mengganggu oksigenasi organ vital dan jaringan.

c) Tunjukkan/dorong bernafas bibir, selama ekshalasi khususnya untuk pasien dengan fibrosa atau kerusakan parenkim paru.

Rasional :

Membuat tahanan melawan udara luar, untuk mencegah kolaps/penyempitan jalan nafas, sehingga membantu menyebarkan udara melalui paru dan menghilangkan/ menurunkan nafas pendek.

d) Tingkatkan tirah baring/batasi aktivitas dan bantu aktivitas perawatan diri sesuai dengan keperluan.

Rasional :
Menurunkan konsumsi

oksigen/kebutuhan selama periode penurunan pernafasan dapat menurunkan beratnya gejala.

Kolaborasi

a) Awasi seri GDA/nadi oksimetri. Rasional :

Penurunan kandungan oksigen $\left(\mathrm{PaO}_{2}\right)$ dan/atau saturasi atau peningkatan $\mathrm{PaCO}_{2}$ menunjukkan kebutuhan untuk intervensi/ perubahan program terapi.

b) Berikan oksigen tambahan yang sesuai.

Rasional :

Alat dalam memperbaiki

hipoxemia yang dapat terjadi sekunder terhadap penurunan ventilasi/menurunnya permukaan alveolus paru.

4) Diagnosa keperawatan 4; Nutrisi, perubahan, kurang dari kebutuhan tubuh.

Tindakan/intervensi :

Mandiri :

a) Catat status nutrisi pasien pada penerimaan, catat turgor kulit, berat badan dan derajat kekurangan berat badan, integritas mukosa oral, kemampuan/ketidakmampuan menelan, adanya tonus usus, riwayat mual/muntah atau diare.

Rasional :

Berguna dalam mengidentifikasi derajat/luasnya masalah daln pilih intervensi yang tepat.

b) Pastikan pola diet/pengeluaran dan berat badan secara periodik.

Rasional :

Membantu dalam mengidentifikasi kebutuhan/kekuatan khusus, pertimbangkan keinginan individu dapat memperbaiki masukan diet.

c) Awasi pemasukan/pengeluaran dan berat badan secara periodik

Rasional :

Berguna dalam mengukur keefektivan nutrisi dan dukungan cairan.

d) Selidiki anoreksia, mual, muntah, dan catat kemungkinan hubungan dengan obat, awasi frekuensi, volume, konsistensi faeces.

Rasional :

Dapat mempengaruhi pilihan diet dan mengidentifikasi area pemecahan. 
e) Dorong dan berikan periode istirahat baring.

Rasional :

Membantu menghemat energi

khususnya bila kebutuhan metabolik meningkat saat demam.

f) Berikan perawatan mulut sebelum dan sesudah tindakan pernafasan.

Rasional :

Menurunkan rasa tak enak karena sisa sputum atau obat untuk pengobatan respirasi yang merangsang pusat muntah.

g) Dorong makan sedikit dan sering dengan makanan tingi protein dan karbohidrat.

Rasional :

Memaksimalkan masukan nutrisi tanpa kelemahan yang tak perlu/kebutuhan energi dari makan makanan yang banyak menurunkan iritasi gaster.

h) Dorong orang terdekat untuk membawa makanan dari rumah dan untuk membagi dengan pasien kecuali kontra indikasi.

Rasional :

Membuat lingkungan sosial lebih normal selama makan dan membantu memenuhi kebutuhan personal dan kultural.

Kolaborasi :

a) Rujuk ke ahli diet untuk menentukan komposisi diet.

Rasional :

Memberikan bantuan dalam perencanaan diet dengan nutrisi adekuat untuk kebutuhan metabolik dan diet.

b) Konsul dengan terapi pernapasan untuk jadwal pengobatan $1-2$ jam sebelum/setelah makan.

Rasional :

Dapat membantu menurunkan insiden mual dan muntah sehubungan dengan obat atau efek pengobatan pernafasan pada perut yang penuh.

c) Awasi pemeriksaan laboratorium, cairal BUN, protein serum, dan albumin.

Rasional :

Nilai rendah menunjukkan mal nutrisi dan menunjukkan kebutuhan intervensi/perubahan program terapi.

d) Berikan antipiretik tepat.

Rasional :
Dengan meningkatkan kebutuhan metabolik dan juga mengkonsumsi kalori.

5) Diagnosa keperawatan ; kurang pengetahuan (kebutuhan belajar) mengenai kondisi, aturan tindakan dan pencegahan.

Tindakan/intervensi :

Mandiri :

a) Kaji kemampuan pasien untuk belajar, contoh tingkat takut, masalah kelemahan, tingkat partisipasi, lingkungan terbaik di mana pasien dapat belajar, seberapa banyak isi, media terbaik, dan siapa yang terlibat.

Rasional :

Belajar tergantung pada emosi dan kesiapan fisik dan ditingkatkan pada tahap individu.

b) Identifikasi gejala yang harus dilaporkan ke perawat, contoh nemopthiasis: nyeri dada, demam, kesulitan bernafas, kehilangan pendengaran, vertigo.

Rasional :

Dapat menunjukkan kemajuan atau pengaktifan ulang penyakit atau efek obat yang memerlukan evaluasi lanjut.

c) Terangkan pentingnya mempertahankan protein tinggi dan diet karbohidat dan pemasukan cairan adekuat.

Rasional :

Memenuhi kebutuhan metabolik membantu meminimalkan kelemahan dan meningkatkan penyembuhan. Cairan dapat mengencerkan/mengeluarkan sekret.

d) Berikan instruksi dan informasi tertulis khusus pada pasien untuk rujukan contoh : jadwal obat.

Rasional :

Informasi tertulis menurunkan hambatan pasien untuk mengingat sejumlah besar informasi.

Pengulangan menguatkan belajar.

e) Jelaskan dosis obat, frekuensi pemberian, kerja yang diharapkan dan alasan pengobatan yang lama, kaji potensial interaksi, dengan obat/subtansi lain.

Rasional :

Meningkatkan kerjasama dalam program pengobatan dan mencegah penghentian obat sesuai perbaikan kondisi pasien. 
f) Kaji potensial efek samping pengobatan (contoh mulut kering, konstipasi, gangguan penglihatan, sakit kepala, hipertensi ortostastik) dan pemecahan masalah.

Rasional :

Mencegah/menurunkan

ketidaknyamanan sehubungan dengan terapi dan meningkatkan kerjasama dalam program.

g) Tekankan kebutuhan untuk tidak minum alkohol sementara minum INH.

Rasional :

Kombinasi INH dan alkohol telah menunjukkan peningkatan insiden hepatitis.

h) Rujuk untuk pemeriksaan mata setelah memulai dan kemudian tiap bulan selama minum ethambutol.

Rasional :

Efek samping utama menurunkan penglihatan, tanda awal menurunnya kemampuan untuk melihat warna hijau.

i) Dorong pasien/orang terdekat untuk menyatakan takut/masalah. Jawab pertanyaan secara nyata catat lamanya penggunaan penyangkalan

Rasional :

Memberikan kesempatan untuk memperbaiki kesalahan konsepsi/peningkatan ansietas, ketidakadekuatan keuangan/ penyangkalan lama dapat mempengaruhi koping dengan/manajemen tugas untuk meningkatkan dan mempertahankan kesehatan.

d. Pelaksanaan

1) Pelaksanaan adalah realisasi rencana tindakan dalam proses keperawatan dan sangat menuntut kemampuan intelektual, keterampilan dan tehnik keperawatan.

2) Pelaksanaan keperawatan sesuai dengan rencana keperawatan yang didasari kebutuhan klien untuk mengurangi atau mencegah masalah serta merupakan pengelolaan atau perwujudan rencana keperawatan pada seorang klien.

3) Ada 2 syarat hasil yang diharapkan dalam pelaksanaan perawatan yaitu

a) Adanya bukti bahwa klien dalam proses menuju perawatan atau telah tercapai tujuan yang diinginkan.

b) Adanya bukti bahwa tindakan keperawatan dapat diterima klien.

4) Proses pelaksanaan perawatan yaitu

a)Merencanakan perawatan, segala informasi yang tercakup dalam rencana keperawatan, merupakan dasar atau pedoman dalam tindakan.

b) Mengidentifikasi reaksi klien, dituntut usaha yang tidak tergesa-gesa dan teliti agar dapat menemukan reaksi klien sebagai akibat tindakan keperawatan

Evaluasi

1) Evaluasi adalah penilaian keberhasilan rencana keperawatan dalam memenuhi kebutuhan klien.

2) Pada klien tuberkulosis paru dapat dinilai hasil pelaksanaan perawatan dengan melihat catatan perkembangan, hasil pemeriksaan klien, melihat langsung keadaan dan keluhan klien, yang timbul sebagai masalah berat.

3) Evaluasi harus berdasarkan pada tujuan yang ingin dicapai.

4) Evaluasi dapat dilihat 4 kemungkinan yang menentukan tindakan-tindakan perawatan selanjutnya antara lain :

a) Apakah pelayanan keperawatan sudah tercapai atau belum.

b) Apakah masalah yang ada telah terpecahkan/teratasi atau belum.

c) Apakah masalah sebagian terpecahkan/tidak dapat dipecahkan.

d) Apakah tindakan dilanjutkan atau perlu pengkajian ulang.

\section{Metode Penelitian}

Untuk memperoleh bahan-bahan penyusunan Karya Tulis Ilmiah ini penulis menggunakan tehnik pengumpulan data sebagai berikut:

1. Studi kepustakaan (Library Research) yang dikumpulkan dari bahan-bahan bacaan dan materi yang bersumber dari literature yang berhubungan dengan masalah yang penulis hadapi.

2. Studi kasus (Case study) yaitu melaksanakan asuhan keperawatan pada keluarga meliputi pengkajian, perencanaan, pelaksanaan tindakan keperawatan dan evaluasi tindakan keperawatan. Untuk memperoleh data dan informasi yang dibutuhkan, penulis menggunakan tehnik sebagai berikut:

a. Wawancara 
Melakukan tanya jawab secara langsung dari beberapa pihak yang dapat memberikan data ang dibutuhkan.

b. Observasi

Mengamati dan mengikuti secara langsung keadaan lingkungan dan pola hidup keluarga.

c. Studi dokumentasi

Mengambil beberapa pencatatan dan arsiparsip melalui puskesmas ataupun petugas puskesmas (petugas kesehatan).

d. Pengkajian Fisik

Melakukan pengkajian Fisik kepada seluruh anggota Keluarga.

3. Diskusi

Diskusi dengan keluarga, pembimbing, perawat, dokter dan petugas kesehatan lainnya yang terkait dengan kasus klien.

\section{Pembahasan}

Setelah melakukan asuhan keperawatan pada keluarga Ny. H dengan anggota keluarga menderita TB Paru selama 3 hari dari tanggal 17 s.d 19 Juli 2009, penulis akan menguraikan kesenjangan antara tinjauan teoritis dengan kasus yang ada. Untuk memudahkan pembahasan, penulis menggunakan pendekatan proses keperawatan yaitu mulai dari proses pengkajian, intervensi keperawatan, implementasi keperawatan dan evaluasi.

\section{Gangguan Kesehatan Keluarga; Penyakit TB} Paru

\section{Pengkajian}

Sesuai hasil pengkajian yang dilakukan pada keluarga $\mathrm{Ny}$. H, maka didapatkan anggota keluarga menderita penyakit TB Paru yaitu An. R

Gejala klinik atau keluhan yang dikemukakan pada teori yaitu demam, batuk, sesak nafas, nyeri dada, malaise (tidak ada nafsu makan, sakit kepala, meriang, nyeri otot, keringat malam). Sedangkan keluhan yang ditemukan pada An. $\mathrm{R}$ yaitu batuk berlendir, tekanan darah 100/70 $\mathrm{mmHg}$, nadi $64 \mathrm{x} /$ menit, suhu $36,5^{\circ} \mathrm{C}$ dan pernafasan 20 $\mathrm{x} / \mathrm{menit}$.

Sesuai dengan gejala klinik atau keluhan yang dikemukakan pada teori dan gejala klinik atau keluhan yang dikemukakan pada kasus terjadi kesenjangan yaitu pada kasus tidak ditemukan adanya demam, nyeri dada, malaise, sakit kepala, meriang, nyeri otot, keringat malam. Hal ini disebabkan karena keluhan tersebut umumnya muncul pada awal terjadinya penyakit, sementara pada keluarga Ny. H, An. R menderita batuk sejak \pm 4 bulan yang lalu,dan tengah menjalani pengobatan TB Paru.
Sesuai fungsi pemeliharaan kesehatan, keluarga mempunyai 5 tugas dibidang kesehatan yang terdiri dari :

a. Mengenal masalah kesehatan keluarga.

b. Memutuskan tindakan kesehatan yang tepat bagi keluarga.

c. Merawat keluarga yang mengalami gangguan kesehatan.

d. Memodifikasi lingkungan keluarga untuk menjamin kesehatan keluarga.

e. Memanfaakan fasilitas pelayanan kesehatan disekitarnya bagi keluarga

Sedangkan fungsi pemeliharaan kesehatan pada Keluarga Ny. H ditemukan yaitu :

a. Keluarga kurang mampu mengenal masalah kesehatan tentang penyakit TB Paru

b. Keluarga kurang mampu merawat anggota keluarga yang menderita penyakit TB Paru

c. Keluarga kurang Mampu memelihara lingkungan rumah yang sehat dari TB paru

Sesuai dengan fungsi pemeliharaan kesehatan yang dikemukakan pada teori dan pada klien, tampak adanya kesenjangan yang terjadi 2 fungsi pemeliharaan kesehatan sudah dilaksanakan karena An. $\mathrm{R}$ sudah mau memeriksakan diri ke tempattempat pelayanan kesehatan,dan sudah rutin menjalani program pengobatan dari puskesmas

\section{Perencanaan}

Pada prinsipnya perencanaan yang penulis cantumkan pada kasus tetap mengacu kepada konsep dasar perencanaan asuhan keperawatan keluarga. Dalam hal ini penulis mengangkat sesuai dengan masalah dan kebutuhan yang dihadapi keluarga sehingga tidak ada kesenjangan antara teori dan rencana yang diterapkan pada keluarga.

Adapun perencanaan yang penulis rumuskan sebagai berikut :

a. Beri penyuluhan/penjelasan tentang penyakit TB Paru yaitu :

1) Pengertian.

2) Penyebab.

3) Tanda dan gejala.

4) Cara penularan.

b. Beri penyuluhan kepada keluarga tentang akibat lanjut/komplikasi dari penyakit TB Paru bila tidak diobati.

c. Beri motivasi keluarga untuk membawa anggota keluarga yang sakit ke fasilitas kesehatan yang ada.

d. Beri HE tentang cara perawatan penderita dengan penyakit TB Paru antara lain :

1) Makan makanan bergizi, TKTP.

2) Membuang ludah (sputum) di tempat yang tertutup.

3) Menutup mulut saat batuk.

4) Alat makan dipisahkan.

5) Berobat secara teratur. 
e. Demosntrasikan cara perawatan TB Paru.

f. Beri HE tentang pemeliharaan lingkungan rumah yang dapat menunjang kesehatan yakni :

1) Ventilasi rumah cukup.

2) Cahaya cukup.

3) Kebersihan rumah tetap terjaga.

4) Membuang sputum pada tempat yang tertutup.

Berdasarkan hal tersebut di atas dapat dilihat bahwa perencanaan keperawatan keluarga yang telah disusun dapat mencakup semua tentang penyakit TB paru meliputi: pengertin, penyebab, tanda dan gejala, cara penularan, cara parawatan dan pemeliharaan lingkungan rumah. Penetapan rencana keperawatan keluarga yang sesuai dengan teori sehingga tidak ditemukan adanya kesenjangan dalam penetapan rencana keperawatan keluarga.

\section{Implementasi}

Pada implementasi yang dilaksanakan oleh penulis selalu mengacu pada semua perencanaan yang telah disusun dan dalam hal ini penulis telah memberikan penyuluhan dan pendidikan kesehatan pada keluarga tentang pengertian, penyebab, gejala, perawatan di rumah, pengobatan dan cara pencegahan guna membantu memecahkan masalah yang ada pada keluarga $\mathrm{Ny} . \mathrm{H}$

\section{Evaluasi}

Setelah penulis mengadakan pembinaan pada keluarga Ny. H maka penulis mendapatkan hasil dengan keluarga mengatakan sudah tahu tentang :

a. Keluarga sudah dapat mengenal masalah kesehatan mengenai penyakit TB Paru dibuktikan dengan keluarga mengatakan sudah mengerti tentang penyakit TB Paru.

b. Keluarga sudah mengetahui cara perawatan anggota keluarga yang sakit dibuktikan dengan ungkapan keluarga mengatakan sudah tahu cara perawatan TB Paru yaitu menutup mulut bila batuk, membuang dahak pada tempat yang tertutup, makan makanan bergizi, berobat secara teratur.

c. Keluarga mulai dapat menciptakan lingkungan yang menunjang proses penyembuhan. Hal ini ditandai dengan keluarga mengatakan sudah tahu tentang kesehatan lingkungan yang menunjang pencegahan TB Paru yaitu dengan imunisasi, peningkatan gizi keluarga, tidak meludah di sembarang tempat.

d. Semua masalah tersebut diatas dapat diatasi setelah perawat memberikan pendidikan kesehatan serta motivasi kepada keluarga $\mathrm{Ny}$. $\mathrm{H}$ sesuai dengan masalah keperawatan yang dihadapi. Terjadinya perubahan ini didukung oleh adanya partisipasi keluarga untuk turut serta dalam pelaksanaan asuhan keperawatan.

\section{Resiko Terjadinya Penyakit Akibat Personal Hygiene Yang Kurang \\ 1. Pengkajian}

Pada pengkajian kesehatan personal hygiene ditemukan data sebagai berikut : An. R memiliki gigi yang lubang (caries) dan gigi nampak kotor, pakaian dan kulit An. R nampak kotor, , Ny. H mengatakan anaknya malas menggosok gigi.

Menurut teori personal hygiene meliputi kebersihan badan (mandi, gosok gigi, cuci tangan, dsb) kebersihan pakaian (dicuci, disetrika).

Sedangkan fungsi pemeliharaan kesehatan pada Keluarga Ny. H ditemukan yaitu :

a. Ketidakmampuan keluarga mengenal masalah pentingnya personal hygiene.

b. Ketidakmampuan keluarga mengambil keputusan dalam me-laksanakan tindakan yang tepat

c. Ketidakmapuan merawat anggota keluarga.

d. Ketidakmampuan keluarga untuk menciptakan kebersihan lingkungan

Sesuai dengan fungsi pemeliharaan kesehatan yang dikemukakan pada teori dan pada keluarga, terjadi kesenjangan dimana dari 5 fungsi pemeliharaan kesehatan yang ada dalam teori hanya 4 yang ditemukan pada kasus, 1 yang tidak ditemukan adalah ketidakmampuan keluarga memanfaatkan fasilitas kesehatan. Hal ini disebabkan karena pada keluarga belum terjadi penyakit akibat kurangnya personal hygiene, jadi untuk pemanfaatan pelayanan kesehatan tidak/belum dilaksanakan

\section{Perencanaan}

a. Kaji pengetahuan keluarga tentang personal hygiene; pengertian, jenis-jenis, dampak, dan cara melakukan personal hygiene.

b. Diskusikan bersama keluarga tentang personal hygiene; pengertian, jenis-jenis, dampak, dan cara melakukan personal hygiene.

c. Motifasi keluarga untuk mengunjungi fasilitas pelayanan kesehatan bila ada gangguan kesehatan

d. Beri reinforcement positif

Berdasarkan hal tersebut di atas dapat dilihat bahwa perencanaan keperawatan keluarga yang telah disusun dapat mencakup semua tentang pengertin, jenis-jenis, dampak, dan cara melakukan personal hygiene. Penetapan rencana keperawatan keluarga yang sesuai dengan teori sehingga tidak ditemukan adanya kesenjangan dalam penetapan rencana keperawatan keluarga.

\section{Implementasi}


Pada implementasi yang dilaksanakan oleh penulis selalu mengacu pada semua perencanaan yang telah disusun dan dalam hal ini penulis telah memberikan pendidikan kesehatan pada keluarga tentang pentingnya personal hygiene.

Semua rencana dapat dilaksanakan oleh karena keluarga bersikap terbuka dan menerima terhadap tindakan dan penjelasan yang diberikan oleh penulis.

\section{Evaluasi}

Sebagian masalah tersebut dibawah dapat diatasi setelah perawat memberikan pendidikan kesehatan serta motivasi kepada keluarga $\mathrm{Ny}$. H sesuai dengan masalah keperawatan yang dihadapi. Terjadinya perubahan ini didukung oleh adanya partisipasi keluarga untuk turut serta dalam penerapan asuhan keperawatan hal ini ditandai dengan keluarga mengatakan sudah tahu tentang :

a. Keluarga sudah dapat mengenal mengenal masalah pentingnya personal hygiene. Hal ini ditandai dengan keluarga mengatakan sudah tahu tentang kebersihan diri sendiri

b. Keluarga sudah bisa mengambil keputusan dan melaksanakan tindakan yang tepat.

c. Keluarga belum mampu merawat anggota keluarga karena anggota keluarga masih kecil belum terlalu mengerti tentang Personal hygiene.

d. Keluarga sudah mampu menciptakan kebersihan rumah ditandai dengan keluarga melakukan pembersihan rumah sehingga rumah sudah nampak bersih..

Semua masalah tersebut diatas yang belum teratasi, hal ini disebabkan karena anggota keluarga belum terlalu mengerti tentang pentingnya personal hygiene namun pada prinsipnya telah mengalami kemajuan yang sangat berarti karena keluarga sudah memahami tentang masalah yang ada dan akibatnya jika tidak diatasi.

Resiko Terjadi Penyakit (Diare, Typhoid, DBD) Akibat Lingkungan Yang Tidak Memenuhi Syarat Kesehatan

\section{Pengkajian}

Lingkungan yang sehat dikemukakan pada teori yaitu terlindung dari binatang-binatang yang menyebabkan kuman penyakit, ruangan yang bersih dan cukup, ventilasi rumah cukup, WC bersih, pengaturan alat rumah tangga teratur dan rapih, memiliki sumur dan jarak sumur dengan WC lebih dari 10 meter dan memiliki saluran pembuangan limbah yang tertutup. Sedangkan berdasarkan data yang ditemukan pada keluarga $\mathrm{Ny}$. $\mathrm{H}$ terjadi kesenjangan yaitu pada keluarga ini ditemukan data sbb: ventilasi yang kurang, pencahayaan yang kurang, pengaturan perabot rumah tangga yang tidak teratur, dan keadaan dapur dan ruang makan yang kotor. Hal ini disebabkan karena keluarga belum menyadari tentang pentingnya kebersihan lingkungan yang dapat menunjang kesehatannya .

Sedangkan fungsi pemeliharaan kesehatan pada Keluarga Ny. H ditemukan yaitu :

a. Ketidakmampuan keluarga mengenal masalah kesehatan lingkungan

b. Ketidakmampuan keluarga mengambil keputusan dalam me-laksanakan tindakan yang tepat.

c. Ketidakmampuan keluarga untuk menciptakan kebersihan lingkungan

Sesuai dengan fungsi pemeliharaan kesehatan yang dikemukakan pada teori dan pada keluarga, terjadi kesenjangan dimana dari 5 fungsi pemeliharaan kesehatan yang ada dalam teori hanya 3 yang ditemukan pada kasus, 2 yang tidak ditemukan adalah ketidakmampuan keluarga merawat anggota keluarga dan ketidakmampuan keluarga memanfaatkan fasilitas kesehatan. Hal ini disebabkan karena pada masalah kesehatan lingkungan, kedua diagnosa ini memang tidak memungkinkan untuk ditegakkan karena lebih ditujukan pada gangguan kesehatan anggota keluarga.

\section{Perencanaan}

a. Beri penjelasan kepada keluarga tentang lingkungan rumah yang memenuhi syarat kesehatan, antara lain :

1) Ventilasi cukup.

2) Cahaya cukup.

3) Ada tempat sampah yang tertutup.

4) WC yang memenuhi syarat.

5) SPAL yang memenuhi syarat kesehatan.

6) Beri penyuluhan kepada keluarga tentang manfaat pemeliharaan kesehatan lingkungan.

b. Beri penjelasan tentang akibat bila lingkungan rumah tidak memenuhi syarat kesehatan.

c. Beri penjelasan kepada keluarga tentang cara memelihara lingkungan yang memenuhi syarat kesehatan.

d. Beri penjelasan tentang cara membuat tempat sampah yang memenuhi syarat.

\section{Implementasi}

Pada implementasi yang dilaksanakan oleh penulis selalu mengacu pada semua perencanaan yang telah disusun dan dalam hal ini penulis telah memberikan pendidikan kesehatan pada keluarga tentang lingkungan rumah yang tidak memenuhi syarat kesehatan, manfaat pemeliharaan kesehatan lingkungan dan dampak lingkungan rumah yang tidak memenuhi syarat kesehatan.

Semua rencana dapat dilaksanakan oleh karena keluarga bersikap terbuka dan menerima terhadap 
tindakan dan penjelasan yang diberikan oleh penulis.

\section{Evaluasi}

a. Keluarga sudah dapat mengenal masalah kesehatan lingkungan yang ada. hal ini ditandai dengan keluarga mengatakan sudah tahu tentang lingkungan rumah yang memenuhi syarat yaitu : ventilasi cukup dengan membuka jendela, cahaya matahari yang masuk ke dalam rumah cukup, ada WC, SPAL dan tempat sampah.

b. Keluarga sudah dapat mengambil keputusan yang tepat dalam pemeliharaan kesehatan lingkungan, hal ini ditandai dengan adanya pernyataan keluarga yang menyatakan akan melakukan pembersihan lingkungan secara rutin.

c. Keluarga sudah dapat menciptakan lingkungan yang menunjang kesehatan anggota keluarga. Hal ini ditandai dengan keluarga pernyataan keluarga yang mengatakan telah mengepel rumahnya.

Semua masalah tersebut diatas dapat diatasi setelah perawat memberikan pendidikan kesehatan serta motivasi kepada keluarga $\mathrm{Ny}$. H sesuai dengan masalah keperawatan yang dihadapi. Terjadinya perubahan ini didukung oleh adanya partisipasi keluarga untuk turut serta dalam pelaksanaan asuhan keperawatan.

\section{Kesimpulan dan Saran}

Berdasarkan hasil Pelaksanaan penerapan Asuhan Keperawatan Keluarga Ny . H dengan Anggota Keluarga Menderita TB Paru di Wilayah Kerja Puskesmas Mangasa RT A RW 08 Kelurahan Mangasa Kecamatan Tamalate Kota Makassar, dapat diambil beberapa kesimpulan dan saran sebagai berikut :

\section{Kesimpulan}

1. Dalam melaksanakan pengkajian terhadap keluarga Ny."H" penulis memperoleh data bahwa anggota keluarga $\mathrm{Ny}$. $\mathrm{H}$ mengalami penyakit TB Paru. Gejala penyakit TB Paru dalam konsep dasar tidak jauh beda dengan tinjauan kasus namun ada beberapa gejala yang tidak muncul seperti tidak ada nafsu makan, keringat malam, sakit kepala, meriang, nyeri otot dan demam. Hal ini disebabkan karena keluhan tersebut umumnya muncul pada awal terjadinya penyakit, sementara pada klien An. R menderita batuk sudah lama $( \pm 4$ bulan yang lalu).

2. Pada asuhan keperawatan keluarga Ny. H ditemukan 3 masalah kesehatan yaitu anggota keluarga menderita penyakit TB Paru, resiko terjadinya penyakit akibat personal hygiene yang kurang. Dan resiko terjadinya penyakit (diare, typhoid, DBD) akibat lingkungan yang tidak memenuhi syarat kesehatan dan Dalam perencanaan penulis melibatkan keluarga dalam menentukan masalah dan kebutuhan keperawatan keluarga, menentukan prioritas masalah, memilih tindakan yang tepat dalam proses perawatan TB Paru. Intervensi yang dilakukan untuk mengatasi masalah tersebut yaitu memberikan penyuluhan dan motivasi kepada keluarga.

3. Tahap pelaksanaan asuhan keperawatan keluarga Ny."H" dengan anggota keluarga menderita TB Paru didasarkan pada perencanaan yang telah disusun penulis bersama keluarga.

4. Pada tahap evaluasi masalah yang ditemukan tidak semuanya dapat teratasi (hanya sebahagian). Hal ini disebabkan karena terbatasnya waktu, pola kebiasaan lingkungan yang tidak menunjang kesehatan dan sumber daya keluarga

5. Penerapan proses keperawatan pada keluarga terbukti sangat efektif terutama dalam mengatasi masalah-masalah kesehatan yang ada dalam suatu keluarga.

\section{Saran}

Berdasarkan kesimpulan dari asuhan keperawatan keluarga yang telah diuraikan diatas, maka penulis memberikan beberapa saran kepada pembaca dan petugas kesehatan :

1. Pengkajian keperawatan keluarga harus dilakukan secara sistematis dan komprehensif untuk memperoleh data yang seakurat mungkin dalam menegakkan diagnosa keperawatan.

2. Pendidikan kesehatan atau penyuluhan perlu diberikan kepada individu, keluarga dan masayarakat secara luas dan menyeluruh. Hal ini diharapkan agar individu, keluarga dan masyarakat berperan aktif dalam memelihara dan meningkatkan derajat kesehatan khususnya penyakit TB paru.

3. Setelah ditemukan kasus penyakit khususnya gangguan sistem pernafasan TB paru hendaknya perawat kesehatan masyarakat segera mengadakan penyuluhan terhadap masyarakat dan pembinaan khususnya pada keluarga Ny.'H” yang menderita TB paru.

4. Rencana keperawatan yang telah dilaksanakan agar tetap menjadi program bagi keluarga Ny."H" dan mempertahankan apa yang telah didapatkan selama binaan. Dalam pelaksanaan intervensi hendaknya disesuaikan dengan situasi dan kondisi yang dimiliki oleh keluarga binaan.

5. Perlu adanya kerjasama yang baik antara keluarga dengan petugas kesehatan agar kasus penyakit yang dihadapi dapat ditangani secara kooperatif dan hasil yang didapatkan dari evaluasi sesuai dengan kriteria yang diharapkan. 
6. Melihat waktu pelaksanaan perawatan pada klien dan keluarga yang cukup singkat dan hasil dari implementasi keperawatan yang diberikan dapat terlihat secara menyeluruh maka diharapkan pada pihak terkait dalam hal ini pihak puskesmas dapat melanjutkan proses keperawatan yang telah diberikan untuk melihat hasil proses yang diberikan dan sekaligus menentukan tindak lanjut jika memang perlu.

\section{DAFTAR PUSTAKA}

Alimul Hidayat, A. Azis, (2002), Dokumentasi Proses Keperawatan, EGC : Jakarta

Departemen Kesehatan RI, (1987), Tekhnik Perawatan Dasar, Cetakan ke 3, PT. Granesia, Jakarta.

Depkes RI, (1999), Indonesia Sehat 2010 ; Visi Baru, Misi, Kebijakan dan Strategi Pembangunan Kesehatan, Jakarta.

Doenges, (2002), Rencana Asuhan Keperawatan, EGC : Jakarta

Effendy, Nasrul (1998), Dasar-Dasar Keperawatan Kesehatan Masyarakat, Edisi 2 EGC. Jakarta.

Friedman, Marilynn M, (1998), Keperawatan Keluarga Teori dan Praktek, EGC, Jakarta.

Mansjoer, Arif. (2000), Kapitaselekta kedokteran, Edisi 3, Jilid 1. FKUI-Media Aesculapius: jakarta.

Mubarak Iqbal Wahid, dkk, (2006), Buku Ajar Ilmu Keperawatan Komunitas 2, Sagung seto, Jakarta.

Price, S. A, (1995), Patofisiologi; Konsep Klinis Proses-proses Penyakit. Buku 2 Edisi IV, Penerbit Buku Kedokteran; EGC. Jakarta.

Slamet, J. S, (2002), Kesehatan Lingkungan, Gajah Mada University Press, Jogjakarta.

Smeltzer, Suzanne C \& Brenda G. Bare. (2001), Keperawatan Medikal Bedah, Vol 1, Edisi 8, EGC : Jakarta.

Soeparman, (2001), Ilmu Penyakit Dalam, jilid II, penerbit : Balai Penerbit FKUI, Jakarta.

Suprajitno, (2004), Asuhan Keperawatan Keluarga Aplikasi dalam Praktik, Penerbit Buku Kedokteran; EGC. Jakarta. 